\title{
Potentials of Alternative Propulsion Systems for Railway Vehicles - A Techno-Economic Evaluation
}

\author{
Johannes Pagenkopf, M.Sc. \\ German Aerospace Center, \\ Institute of Vehicle Concepts, \\ Rutherfordstraße 2 \\ 12489 Berlin, Germany \\ Email: johannes.pagenkopf@dlr.de
}

\author{
Stefan Kaimer, M.Sc. \\ German Aerospace Center, \\ Institute of Vehicle Concepts, \\ Rutherfordstraße 2 \\ 12489 Berlin, Germany \\ Email: stefain.kaimer@dlr.de
}

\begin{abstract}
This paper discusses alternative propulsion systems for heavy railway vehicles. First, edge conditions such as drivers and roadblocks for the implementation of alternative propulsions in railway vehicles are discussed. For operations on a non-electrified railway route, the required main propulsion components of a battery electric multiple unit and of a fuel cell multiple unit are roughly dimensioned and economically compared with a benchmark diesel multiple unit, the BR 612 of Deutsche Bahn. The nonelectrified route from UIm to Oberstdorf was considered as a reference route for the simulation and drivetrain layout. Our analysis finds that alternative drive concepts hold a high potential for future railway vehicles, depending on the boundary conditions.
\end{abstract}

Keywords - railway; life cycle costs; alternative propulsion; fuel cell; battery electric; simulation.

\section{INTRODUCTION}

Although electrified vehicles have been in use in railway applications for over 100 years, vehicles with energy-independent, diesel based drives are still of a great importance for the world's railway networks. As of today, only $51 \%$ of heavy mainline railways in Europe are electrified. In Asia $(<35 \%)$, Africa $(<16 \%)$ and in America $(<1 \%)$, the rate is even lower [1]. Capital intensive overhead electrification is done primarily on routes with a high degree of track utilization, as it may not prove economically viable in case of low line utilization. Moreover, increasing fuel prices and stricter emission regulations pose a challenge for railway operators that rely on diesel propulsion today and may direct their attention towards alternative propulsion systems in the future.

\section{SCOPE}

This paper addresses the use of non-conventional propulsion systems in heavy passenger railway vehicles on non-electrified routes.
First, relevant alternative propulsion systems are briefly discussed. Then, the drivetrain's potentials and drawbacks in terms of technical, economical and operational aspects are briefly addressed with a particular focus on battery electric multiple units (BEMU) and fuel cell multiple units (FCMU).

In the subsequent case study, the drivetrains of a BEMU and a FCMU are roughly designed and economically evaluated against a conventional diesel multiple unit (DMU).

\section{Alternative Propulsion SyStems IN (HeAVy) RaIL SYSTEMS}

This chapter gives an overview of relevant alternative drivetrain technologies for railway vehicles. Furthermore, motives for their application and roadblocks constraining a fast uptake of these novel drivetrains are discussed.

\section{A. Definition and Main Types of Alternative Propulsion} Systems

The term alternative propulsion system denotes drivetrain architectures that do not use conventional diesel propulsion systems on non-electrified lines.

\section{1) Motivation}

Alternative drives hold the potential to reduce vehicle emissions and in the long-term also to cut operating costs. By using renewable energy to fuel the trains, emissions can be reduced significantly. If an on-board energy storage device (e.g. a battery) is used, energy generated by dynamic braking can be recovered, lowering the overall energy demand. In addition, these energy storages can be used for network stabilization, if the vehicle is used on electrified tracks as well. Last but not least, vehicles with alternative drives can realize a silent and (locally) emission-free operation. In this context, battery electric drives and fuel cell hybrid drives are particularly suitable for alternatively propelled railway vehicles. Although there are many more 
alternatives to a classic diesel propulsion, such as a hybridization of a diesel powertrain (e.g. in combination with battery/supercap/flywheel) or the usage of alternative fuels, such as liquefied natural gas, none of these options allows (theoretically) zero-emission operation as of today. Therefore the technical and economic feasibility of a BEMU and a hybridized FCMU will be evaluated in this paper.

\section{2) Edge conditions}

Compared to passenger road cars, railway vehicles are characterized by long power-on times, long operational lifetimes and high power and energy demands. Furthermore railway components must withstand harsh environmental conditions (i.e. shock and vibration). In return, the power demand is partly predictable. [2]

As load characteristics differ among railway vehicle classes, the suitability of alternative drives has to be evaluated for each vehicle class separately. Especially for high speed trains and high-capacity freight trains, aboveaverage energy and power demands in conjunction with long ranges and only few intermediary stops are characteristic. Instead of equipping these vehicles with batteries or fuel cells for traction purposes, track electrification is usually conducted. In any case, these vehicles are often operated on electrified tracks. In contrast to this, light rail vehicles (LRV), regional trains and shunting locos are more eligible for the usage of alternative propulsion systems. [2]

\section{3) Applications}

Whereas most efforts to implement alternative drives had been geared towards road vehicles, there have been approaches for alternative drives in railway vehicles as well. Especially in the past years, there has been an increasing effort in research and development of corresponding railway vehicle concepts. However, most of the realized vehicles are still test samples or prototypes.

An example for a hybridized DMU is the BR 642 (Siemens Desiro) of Westfrankenbahn. This vehicle is designed as a parallel hybrid and is equipped with lithium-ion batteries in addition to the diesel powertrain. [3]

Energy storages, such as batteries, supercaps or flywheels, are used for LRVs, too. On-board energy storages are applied to bridge non-electrified line sections or for energy recovery when braking. Kawasaki SWIMO, Bombardier Mitrac, ALSTOM Citadis and Siemens Sitras HES are just a few samples for such LRVsolutions. [4],[5],[6],[7]

In the 1950s, the BR 515, a BEMU, carrying lead acid batteries with a capacity between $350 \mathrm{kWh}$ and $550 \mathrm{kWh}$ was introduced in Germany. The BR 515 was decommissioned in 1995, due to insufficient vehicle dynamic qualities, an inadequate range and high maintenance costs. [8]

Modern battery technology contributes to a revival of battery electric railway vehicles. Especially for shunting locos, such as the ALSTOM H3 platform or the Vossloh $\mathrm{G} 6$, traction batteries have already been in service. [9],[10]

In addition to novel energy storages, also alternative energy converters (i.e. fuel cells) are applied in railway vehicles. There have already been mining locos equipped with fuel cells and batteries for traction purposes. [11] Beyond that, a shunting loco by Vehicle Projects Inc. and a main line fuel cell hybrid multiple unit by the Japanese Railway Technical Research Institute (RTRI) have been build. These vehicles use fuel cells with rated powers of $250 \mathrm{~kW}$ and $100 \mathrm{~kW}$ respectively in combination with batteries. [12],[13]

\section{B. Drivers in Favor of an Adoption of Alternative Propulsion Systems}

There is a range of trends that might promote an adoption of alternative propulsion systems in railways.

\section{1) Oil Price and Emissions Regulations}

In case of low line throughputs, high expenditures into continuous wayside energy infrastructure do often not justify overhead electrification from an economical viewpoint. Thus, on diesel-operated non-electrified lines, the uptake of alternative drivetrains might be stimulated in view of oil price rises. Historic oil price trends and peak oil discussions indicate a further rise. In 2011 prices, the OECD had predicted an increase in crude oil prices until 2020 by $33 \%$ to $127 \%$, depending on underlying assumptions, compared to 2012 levels. [14] In terms of total lifetime costs, expenses of rail operators for fuel may comprise up to $75 \%$ of total life cycle costs, as [15] argues.

Besides rising fuel prices, tightening emission legislations, especially in the EU (Stages) and the US (Tier), for non-road applications in conjunction with fuel taxation and regional and local efforts to push low-noise and locally-emission-free operations might help paving the way for alternative drivetrains in the rail sector. 


\section{2) Alternative Propulsion Systems in the Road-Sector}

The automotive, bus and also light rail sectors have seen a lot of research and trial projects on alternative drivetrain and storage systems in the past years. Spill overs in particular from busses and trucks in the fuel cell and battery technology might help to contribute to their adoption in the more technology persistent railway sector.

This applies also to the recharging and fueling infrastructure. Thus, technology transfer or shared usage of energy infrastructure, for instance by buses and trains, may become more relevant in the coming years.

\section{Roadblocks}

Apart from these drivers, there is, however, also a range of technological, operational, regulatory and economical barriers to a profound adoption of alternative drivetrains, especially of fuel cell and battery electric trains that need to be addressed in this context.

\section{1) Technical and operational}

The degree of technological maturity and commercialization of traction batteries and fuel cells especially for railway vehicles' energy and power requirements varies, but is in general as of today still very limited. And so are operational experiences with alternative drivetrains in day-to-day railway services. Apart from a couple of research projects and small-scale test applications, there is nearly no series-production of railway vehicles using alternative propulsions today. To become real system alternatives to DMUs, alternative vehicle concepts such as BEMUs and FCMUs need the buildup of a reliable railway-certified supply base for alternative drivetrain and energy storage components. Not least, adapted, tested and approved workshops, depots and refueling/recharging facilities are required, accompanied by a skilled workforce.

In terms of operational flexibility, energy infrastructure planning and charging and refueling schemes need to consider timetable boundary conditions and stations' specific constructional and safety conditions. Especially in the case of BEMUs, long re-charging times could necessitate fundamental timetable adaptions on DMUoperated routes.

Moreover, unless vehicles cannot be retrofitted with higher storage volumes, a major drawback in terms of long-term planning of railways could be that FCMU and BEMU might be limited to certain ranges and routes. In reality, extending the available storage capacity might be restricted due to mass and volume limits on railcars, which confines flexibility considerably (a DMU in contrast is less limited in its range profile as diesel fuel has a high energy density, thus requiring less space and mass on the vehicle, compared to BEMU and FCMU). Furthermore, infrastructure managers need to provide appropriate recharging or refueling facilities respectively.

Not least, compliance with operator-specific requirements in terms of reliability, availability, maintainability and safety (RAMS), stipulated in the call for tenders' functional requirements needs to be achieved.

\section{2) Regulatory}

For BEMU and FCMU, standardization and homologation processes in order to achieve national and supra-national railway authorities' approvals necessitate extensive and long-lasting tests, certifications and proofs. There is, for example, the issue of demonstrating safe operations of fuel cells or traction batteries in trains that need to be addressed to the approval bodies in the upcoming years.

\section{3) Economical}

Since railway manufacturers are, as opposed to largequantity road vehicle manufacturers, characterized by producing only small series, with lots often not exceeding 20 or 30 vehicles, the one-off $R \& D$ expenses, testing and homologation costs need to be allocated to a small number of vehicles. This cost-increasing factor affects the competitiveness and thus uptake of alternative drivetrains in railways unless there are substantial state subsidies or the cost mark-ups are accepted by the vehicle purchasers. Significant cost-cutting numbers of fuel cells produced for automotive applications cannot be expected before 2020 or 2025 . [16]

Furthermore, risk-averse operators with high cost sensitivities might be hesitant to implement alternative vehicle concepts. The reason is that fuel cells, traction batteries and further alternative drivetrain related components are relatively expensive today, compared to state-of-the art diesel power packs. But, under certain conditions, these concepts might indeed prove costefficient on a life time cost assessment base, as shown in this paper. Especially the prospect of achieving savings in the operational period by cutting the energy bill might reduce reservations against these drive concepts.

\section{CASE STUdy}

This chapter gives a concrete techno-economic appraisal of a BEMU and a FCMU in comparison to a state-of-the art DMU.

\section{A. Setting and Boundary Conditions}

A non-electrified railway route from Ulm to Oberstdorf in Germany is chosen as basis for the 
comparison of the different drivetrain options. Route length is $129.7 \mathrm{~km}$ with 13 intermediary stops and a maximum operational speed of $140 \mathrm{~km} / \mathrm{h}$. Figure 1 shows the route's approximated real-world operational velocity profile, which was regarded for the further research and taken as basis for a simulation. In addition, the height profile is plotted against the route length in the figure.

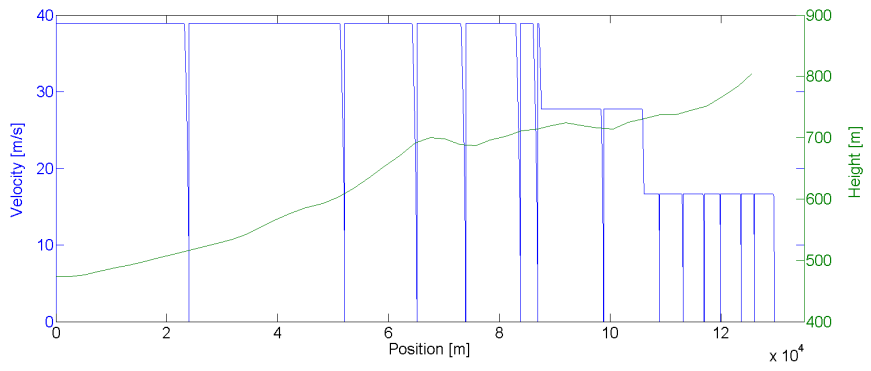

Figure 1: Operational velocity profile and height profile for the regarded reference route Ulm to Oberstdorf

All in all, three different drivetrain configurations have been included in the analysis. Besides a diesel hydraulic multiple unit (DMU), both a battery electric multiple unit (BEMU) and a fuel cell multiple unit (FCMU) are chosen as drivetrain alternatives.

As of today, railway operator Deutsche Bahn applies a diesel multiple unit (BR 612) on the route. Thus, the BR 612 was chosen as a reference vehicle and the simulation parameters have been adapted to the BR 612's driving dynamics parameters accordingly. The train is equipped with two diesel-hydraulic power packs.

\begin{tabular}{|c|c|c|c|}
\hline Vehicle manufacturer & Bombardier Transportation & Tractive effort curves & \\
\hline Operator & Deutsche Bahn AG & 1 & 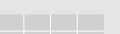 \\
\hline Year of construction & from 2000 & & \\
\hline Country & Germany & & \\
\hline Engine & Cummins QSK 19-R 750 & & \\
\hline Engine output & $559 \mathrm{~kW} / 2100 \mathrm{~min}^{-1}$ & & \\
\hline Transmission input power & $474 \mathrm{~kW} / 2053 \mathrm{~min}^{-1}$ & & \\
\hline Top speed & $160 \mathrm{~km} / \mathrm{h}$ & 20 & $w$ \\
\hline Vehicle weight & $116 t$ & $\begin{array}{rrrr}0 & 2040 & 6 \\
& & \text { Driving }\end{array}$ & $\begin{array}{l}0100120140160 \\
\operatorname{de} V[\mathrm{~km} / \mathrm{h}]\end{array}$ \\
\hline
\end{tabular}

Figure 2: Vehicle data for the reference vehicle BR 612 [17]

As stated in the vehicle data (see Figure 2), $85 \mathrm{~kW}$ of each engine's output is used for auxiliary equipment, such as cooling, lighting and HVAC (heating, ventilation and air condition). In total, this means a maximum auxiliary power of $170 \mathrm{~kW}$ (by both engines). At an average capacity utilization of $80 \%$ [18], $136 \mathrm{~kW}$ of the installed power are used for non-traction purposes.

\section{B. Energy and Power Demand on Reference Route}

The simulation of the reference vehicle was performed using the simulation environment Dymola. The simulation model "SimpleTrain2", which had been developed within the research project Next Generation
Train (NGT) of the German Aerospace Center, was parameterized using vehicle and track data, as shown in the previous paragraph. A fast driving style was considered for the simulation.

Figure 3 shows the desired and the actual speed of the reference vehicle on the route Ulm - Oberstdorf for the vehicle data stated above.

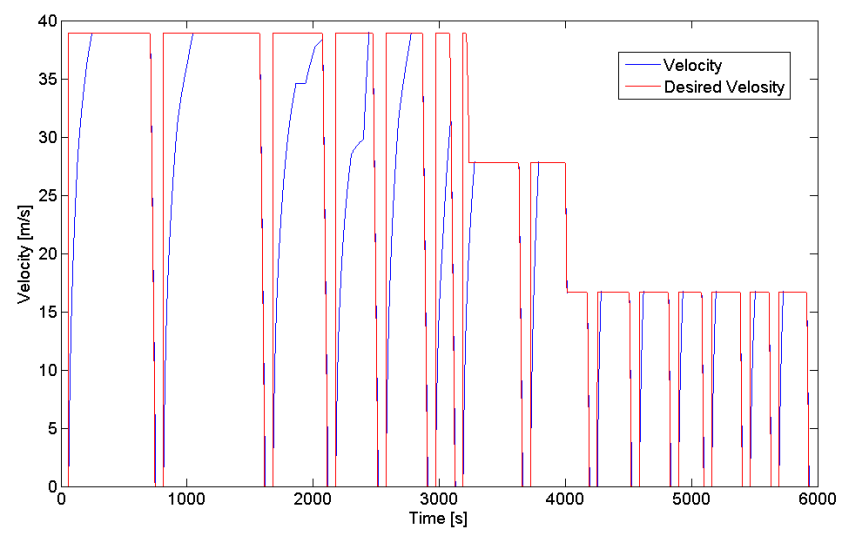

Figure 3: Simulation result for the desired and actual velocity profile

At each station, a stop time of $60 \mathrm{~s}$ was regarded. All in all, a total journey time of $5993 \mathrm{~s}$ is necessary for the reference scenario. Traction power over time at wheel for the reference DMU vehicle is plotted in Figure 4. The resulting traction energy demand at wheel level is $564.7 \mathrm{kWh}$. Taking into consideration the energy demand for the auxiliary equipment, an additional energy of $226.4 \mathrm{kWh}$ has to be provided.

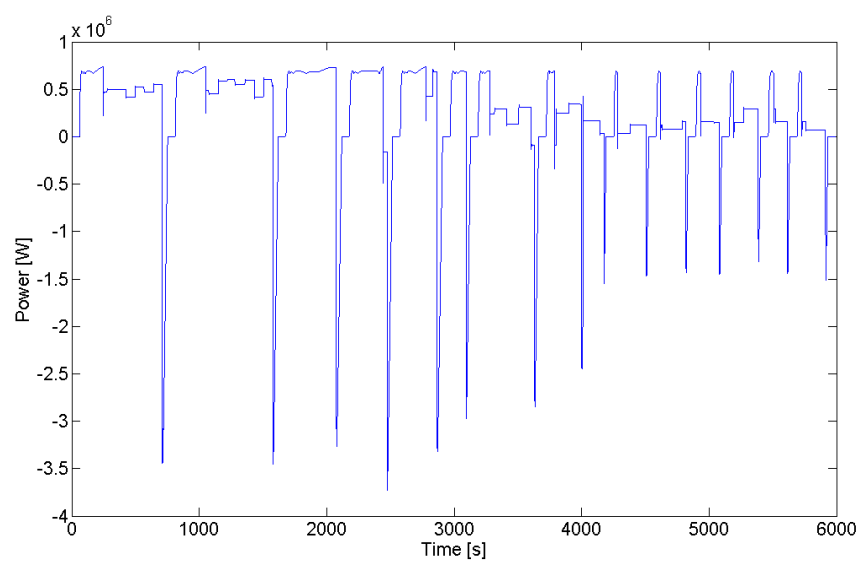

Figure 4: Traction and braking power at wheel level for the reference vehicle (BR 612) on the reference route from Ulm to Oberstdorf

\section{Component Dimensioning}

This paragraph outlines the rough dimensioning of the three drivetrain alternatives. While the drivetrain configuration for the DMU already exists, the components for the BEMU and FCMU, such as battery, fuel-cell, converters, inverters and traction machines, had to be defined independently. 


\section{1) DMU Reference}

Originally, the reference vehicle (BR 612) uses a diesel hydraulic propulsion system. The technical data was already displayed in Figure 2. Two diesel power packs, each having an output power of $559 \mathrm{~kW}$, are utilized for the vehicle. The transmission input power of each power pack is $474 \mathrm{~kW}$. Considering an average efficiency of $77.5 \%$ for the hydrodynamic transmission [19] and $97.8 \%$ for the axle (reversing) gearbox [20], a total traction energy demand of $745.4 \mathrm{kWh}$ has to be provided by the internal combustion engines. Energy demand including auxiliaries is in total $971.8 \mathrm{kWh}$. Assuming an average efficiency of $40 \%$ for the diesel engines [19], $2429.5 \mathrm{kWh}(\approx 2481)$ of diesel are necessary for each journey Ulm - Oberstdorf.

\section{2) $B E M U$}

A battery electric drivetrain configuration requires solely a traction battery as energy storage. In this paper, a direct coupling of the battery and the traction inverter will be regarded (cf. [22]). The inverter is furthermore connected to an electric traction machine. Although the terms "inverter" and "machine" are applied here, multiple of these components have to be used in the vehicle. The basic drivetrain configuration is shown in Figure 5. To calculate the overall efficiency of the drivetrain, the efficiencies of each component have to be included. Setting efficiencies of $97.8 \%$ for the axle gearbox [20], $95 \%$ for the traction motor [21] and $97 \%$ for the traction inverter [20], the overall average drivetrain efficiency is $90 \%$. This value is assumed to be equal for traction and regenerative braking. An appropriate power of the traction motor is $800 \mathrm{~kW}$ in order to configure it adequately to the DMU. The traction inverter should be able to cope with a rated power of $\sim 850 \mathrm{~kW}$ factoring in the efficiency of the traction motor. Taking into account the efficiency of the drivetrain, the traction energy, which has to be provided by the battery, is $627.4 \mathrm{kWh}$. Adding the energy demand for auxiliaries, the overall energy to be stored in the battery is $853.8 \mathrm{kWh}$. Due to the fact that the battery has a strong effect on the vehicles payload, a technology with a high energy and power density should be used. In this paper, a lithium iron phosphate (LFP) battery is considered as a suitable technology. Although other lithium ion chemistries offer a higher energy density, safety characteristics and the high cycle life speak in favor of LFP. [23]

To guarantee an appropriate lifetime of the battery, it should not be completely discharged [24]. Thus, it is assumed, that the battery is operated with a delta state of charge of $60 \%$. Then, the necessary capacity of the battery is $1423 \mathrm{kWh}$. Thereby, life expectancy of the battery is predicted to be 5000 cycles (cf. [25]).
Since regenerative braking is considered in the model, the energy to be delivered by the battery decreases to $777.4 \mathrm{kWh}$. Thus, minimal required battery capacity is reduced to $1296 \mathrm{kWh}$.

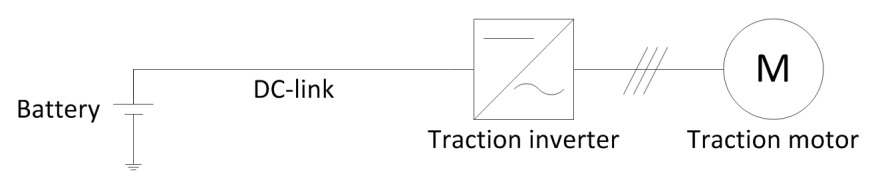

Figure 5: Principle (electric) drivetrain configuration of the BEMU

\section{3) $F C M U$}

Compared to the BEMU, a fuel cell is added in this drivetrain configuration. While the fuel cell delivers the required energy and has a static power output, the battery is used as dynamic energy storage. Thus, the battery delivers power in peak load situations and stores recuperated braking energy. Here, both the battery and the fuel cell are connected to the DC-link via DC/DCconverters. Figure 6 shows the basic FCMU drivetrain configuration.

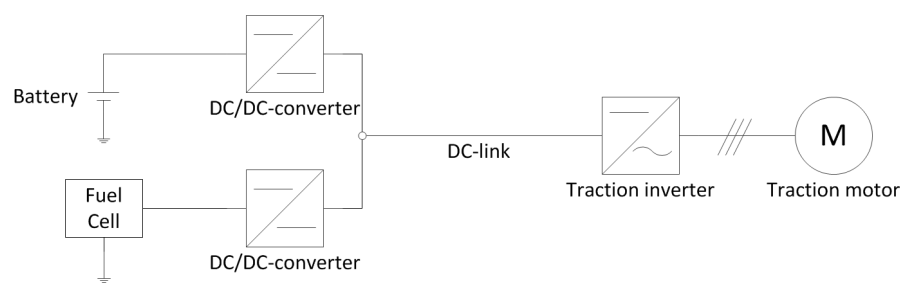

Figure 6: Principle (electric) drivetrain configuration of the FCMU

The efficiency of the additional DC/DC-converters is assumed to be $95 \%$ [26]. Thus, the overall efficiency of the drivetrain is around $85 \%$. To deliver the required demand of energy, the fuel cell has to provide $492 \mathrm{~kW}$ of continuous power. Again $60 \%$ delta state of charge is considered as an appropriate value for the battery. For this reason, the required battery capacity is $265 \mathrm{kWh}$. The resulting state of charge for the battery is displayed in Figure 7. If a fuel cell efficiency of $50 \%$ is assumed [22], $1637 \mathrm{kWh}(\approx 49.2 \mathrm{~kg})$ of hydrogen have to be stored on-board.

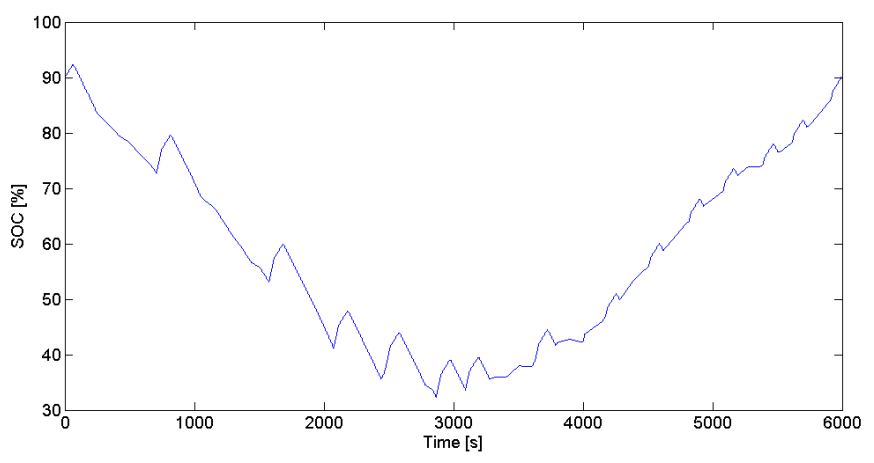

Figure 7: State of charge of the traction battery in the FCMU 
In addition to the traction inverter and the traction motor, two DC/DC-converters are applied. The unidirectional converter for the fuel cell has a rated power of $\sim 500 \mathrm{~kW}$, the bidirectional converter for the battery has a rated power of $\sim 720 \mathrm{~kW}$, allowing for the efficiency of the axle gear, the traction machine and the traction inverter in case of braking.

\section{Costing}

In the following, costs linked to the operation of DMU, BEMU and FCMU are evaluated over the typical operational life of a railway vehicle. Only propulsion and energy related costs directly incurring to a railway operator are included in the calculations. That is, investment and replacement costs of energy converting and storage systems, including their required peripheral components, and the costs of energy needed for train operation.

By this approach, it is assumed that the costs of systems not directly linked to the propulsion system like carbody, interiors, wheelsets, train protection systems, etc. and also the auxiliary systems are equal for DMU, BEMU and FCMU. That, being a simplified approach, helps to focus on the relevant cost differentials between the alternatives considered. Maintenance costs have not been included in the analysis. Operational life is set to 30 years.

The implementation timeframe of novel drivetrain technologies plays a crucial role in the costing process, as especially batteries and fuel cells are predicted to experience fundamental price decreases in the coming years. This, however, requires first, that anticipated automotive induced scale effects, manufacturing and material improvements can be realized in the coming years and that, second, they spill over to the railway sector, making automotive and bus fuel cells and batteries adaptable to railway applications. Three starting year scenarios are analyzed: 2015, 2020 and 2025.

Price data on state-of-the art DMU and electric drivetrain components are derived from a DLR costing database, which is fed by relevant literature and expert data. Price forecast on fuel cells, hydrogen tanks and traction batteries for use in railways are extremely difficult to carry out since such applications are as of today virtually non-existent in series applications. We based our price estimations on meta-analysis of recent (mainly) automotive and bus literature cost studies (e.g. [16],[27]). On these automotive cost data, mark-ups are applied to allow for railway specific requirements (e.g. small series, no economies of scale, railway specific safety stipulations, higher durability and power requirements, lower process automation, etc.).

\section{1) Initial Vehicle Costs and Replacement}

The drivetrain concepts and dimensions elaborated in Section $\mathrm{C}$ are now linked with specific component costs. For each main component, present day and forecast specific costs are related to the required dimension of each component (Figure 8).

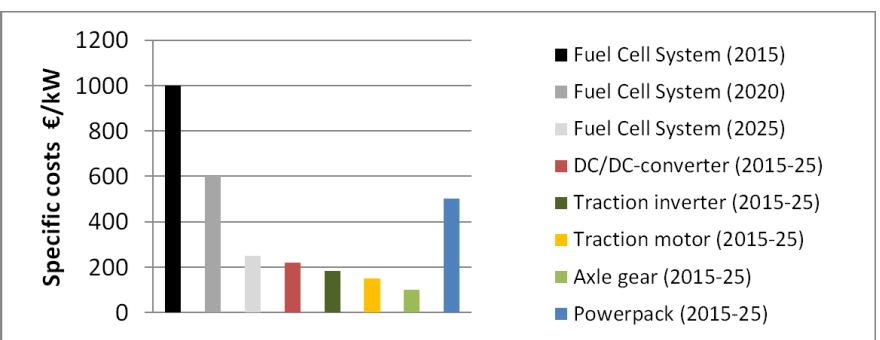

Figure 8: Projection of specific component costs for railway application (2010 prices)

Costs for LFP traction batteries per $\mathrm{kWh}$ are set to $1020 €$ in 2015, $660 €$ in 2020 and $420 €$ in 2025 (2010 prices). At a delta SOC of $60 \%$, cycle life before end-oflife is 5000 . Hour life of fuel cells is set to $15000 \mathrm{~h}$ in 2015 relating to projections of Ballard Power [28] and increasing to 25000 hours in 2025 according to targets set for urban buses [29] (that, however should be further increased to correspond to railway specific requirements). In case standard fuel cells applied in busses can be adapted and implemented to trains, fuel cell prices might shrink even faster in the next 10 years. Based on our costing database, hydrogen tank costs are assumed to decline from $920 €(2015)$ to $490 €$ (after 2025) per $\mathrm{kg}$ of stored hydrogen.

All other electric components have a life expectancy of 15 years whereas all DMU propulsion components require replacement after 8 years. [30]

\section{2) Energy Costs}

Fuel prices (Figure 9) are forecast from 2015 to 2055 and adjusted to 2010 prices; diesel and electricity prices include (German) tax levels. The projection of hydrogen prices does not include energy taxes, reflecting current German taxation legislation, which is, in return a significant source of uncertainty.

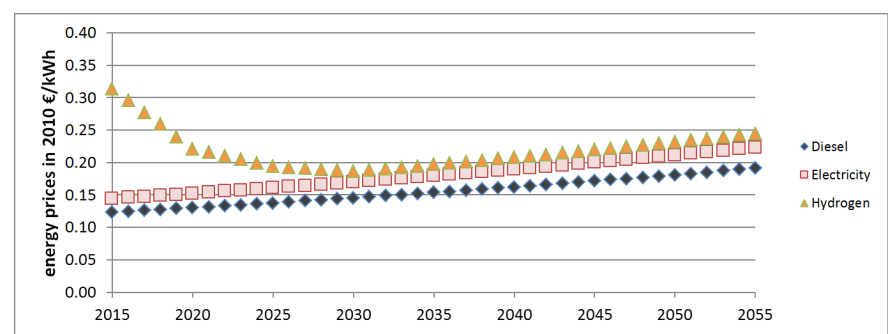

Figure 9: Fuel price projections (2010 prices) 


\section{3) Full Costs and Restrictions}

Total costs were calculated for a 30 year operational period at a $4 \%$ real discount rate and an annual mileage of $200000 \mathrm{~km}$ per vehicle.

Based on Chapter $\mathrm{C}$, an adaption was made in terms of the driving range of the BEMU and FCMU in this section. The propulsion systems were dimensioned in such a way that the combined drivetrain and storage mass of the considered propulsion components of the DMU (we calculated $15800 \mathrm{~kg}$ ) are not surpassed. The critical dimensioning factor is then the energy storage mass. Gravimetric and volumetric energy and power densities of state-of-the art drivetrain and energy storage systems were used.

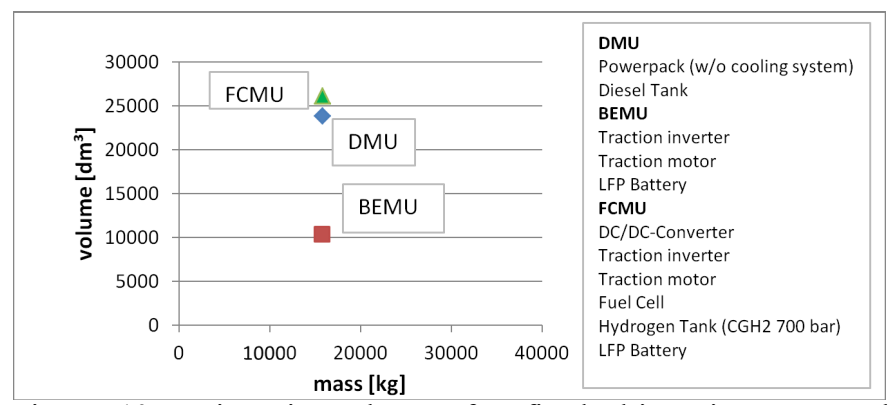

Figure 10: Drivetrain volumes for fixed drivetrain mass and considered components (diesel and hydrogen tanks completely filled)

Figure 10 plots the calculated propulsion systems` volumes and Figure 11 displays the resulting driving ranges.

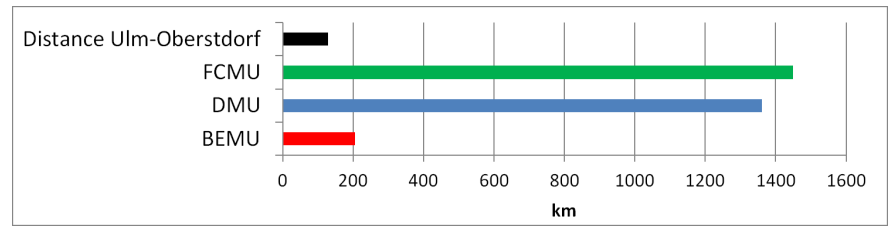

Figure 11: Driving range before refueling for operation on the reference route

Figure 12 gives the cumulated initial equipment, replacement and energy costs for all three propulsion system alternatives. Costs were calculated for train operation start in 2015, 2020 and 2025 (excluding oneoff costs).

The results show that energy costs are the greatest cost contributor for DMU and FCMU, whereas, for the BEMU, component expenditures comprise the biggest cost position. In general, from a LCC perspective, all three drivetrain alternatives are on a more or less equal level, with the FCMU and BEMU gaining advantages over the years due to decreasing component costs. Still, the total picture depends heavily on the energy cost development. Changes in costs of primary energy, tax levels and exemptions, being hard if at all predictable, may lead to deviating results.

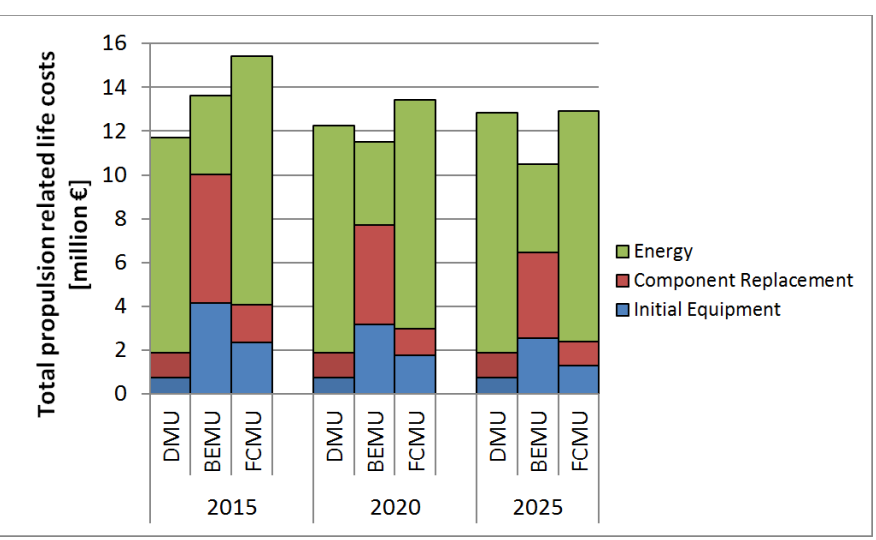

Figure 12: Propulsion related recurring cost projections over 30 years (at a $4 \%$ discount rate) for operational start in 2015, 2020 and 2025 without one-off costs (2010 Euro)

In addition, there are some issues that need to be kept in mind when interpreting the results. First, only propulsion related costs were included in the analysis. Train maintenance, end-of-life costs or revenues, workshop, depot and fueling and charging infrastructure costs were not included in the analysis. However, the diesel, electricity and hydrogen prices all incorporate energy distribution costs.

Furthermore, non-recurring costs for the development, testing, validation and homologation of propulsion systems come on top of the series costs. Especially oneoff costs often form a substantial part of total costs in particular in very small railway typical series. In the end, due to upfront cost sensitivities, train operators might be hesitant to pay massive surcharges for alternative drivetrains in the first place even though these extra costs might be compensated over the life cycle by lower energy costs.

In terms of maintenance, a major influencing issue is the maintenance interval of novel drivetrain components, especially of batteries and fuel cells, which requires further research.

When investigating alternative propulsion systems, mass and volume needs of the energy storage systems pose special consideration as they usually result in a compromise between range and vehicle adaptations. In particular the constrained driving range of the BEMU may in real-world operations be a showstopper for this drivetrain technology on routes like Ulm - Oberstdorf.

\section{CONClusions And Future Work}

The paper was aimed at reviewing the potentials of alternative propulsion systems in railways technically and economically. As alternatives to DMUs, both BEMUs und FCMUs were evaluated in case continuous trackside electrification does not pay out economically. On the non-electrified reference railway route Ulm to Oberstdorf, relevant drivetrain and energy storage 
components of BEMU and FCMU were dimensioned and evaluated in terms of their propulsion related investment and replacement costs as well as the fuel costs over a vehicle's operational life.

As a result, both FCMUs and BEMUs seem to converge to DMUs in terms of costs and even generate savings compared to DMUs in certain cases, not including non-recurring costs. However, in general, operational restrictions due to limited ranges and long recharging times might speak against the BEMU. The FCMU offers more flexibility in this respect. However, questions of reliability and availability of systems and components remain to be answered in this context as well. Further, the existence of certified components and system suppliers in addition to a proper fuel and energy delivery infrastructure is vital for a widespread market diffusion introduction of these alternative propulsion systems.

Still, this work aims at being only the first piece of a comprehensive technology assessment. Further research is required in terms of impacts on other cost aspects like maintenance and wayside infrastructural adaptions. The actual operability of these technologies and the degree of commercialization deserve a closer look and so does, not least, the environmental footprint of the alternatives.

\section{REFERENCES}

[1] UIC, Synopsis

http://www.uic.org/IMG/pdf/synopsis 2011 in pdf.pdf, 2011 accessed 28.01.2014.

[2] S. Kaimer and H. Dittus, Railway vehicles and energy storages A contradiction?, Kraftwerk Batterie 2013, Aachen, Germany, 26.-27. February 2013.

[3] N.N., Deutsche Bahn und MTU stellen Hybridtriebzug vor, Eisenbahntechnische Rundschau (ETR), No. 9, p. 36, September 2012

[4] Kawasaki Heavy Industries Ltd., SWIMO's excellence demonstrated, Scope (Corporate Publication), No. 74, pp. 2-5, January 2008.

[5] M. Klohr and A. Maroschik, Energiespeicher auf Straßen- und Stadtbahnfahrzeugen - das erste Serienprojekt, Elektrische Bahnen (eb), Vol. 110, No. 8-9, pp. 444-451, 2012.

[6] N.N., Alstom to test onboard flywheel energy storage, $\mathrm{http}: / / \mathrm{www} \cdot$ railwaygazette.com/news/business/singleview/view/alstom-to-test-onboard-flywheel-energy-storage.html, 18.01.2013, accessed 28.01.2014.

[7] M. Meinert, Hybrid-EnergieSpeicherSysteme für Energieeffizienz und fahrdrahtlose Energieversorgung, VDE/IZBE-Symposium Elektrische Fahrzeugantriebe und ausrüstungen, Dresden, Germany, 29.-30. November 2012.

[8] S. Fassbinder, Konzepte elektrischer Antriebsausrüstungen für Betrieb ohne Oberleitung, Elektrische Bahnen (eb), Vol. 110, No. 3, pp. 60-65, 2012.

[9] K. Hiller, and M. Binswanger, Lokomotiv-Plattform H3 für Rangierlokomotiven, Elektrische Bahnen (eb), Vol. 111, No. 1, pp. 13-16, 2013.
[10] C. von der Werth, Verschiedene Antriebsmodule auf einer Plattform für einen effizienten Rangierbetrieb, ZEVrail, Vol. 137, No. 6-7, pp. 242-245, 2013.

[11] N.N., Fuel cell trial, Railway Gazette International, April 2012.

[12] A. R. Miller, Fuelcell Locomotives For Zero-Emissions Urban Rail, Statewide Railyard Agreement Technology Symposium, El Monte, California, USA, 28. November 2007.

[13] K. Ogawa, T.Yamamoto et al., The evaluation of endurance running tests of the fuel cells and battery hybrid test railway train, 9th World Congress on Railway Research, Lille, France, 22.-26. May 2011.

[14] J. Fournier, I. Koske, I. Wanner and V. Zipperer, The Price of Oil - Will It Start Rising Again?, OECD Economics Department Working Paper No. 1031, 2013.

[15] Awalegaonkar, K, Britton, J., Curtiss, C. and A. Dünnwald, Travel Infrastructure Logistics - Applying a life-cycle TCO approach to rail assets, McKinsey\&Company, November 2009.

[16] W. Bernhart, S. Riederle and M. Yoon, Fuel cells - A realistic alternative for zero emission?, study by Roland Berger Strategy Consultants, December 2013.

[17] Voith Turbo, BR 612 diesel multiple units of DB Deutsche Bahn $A G$ with $T 312$ br turbo transmission and Scharfenberg coupler type 35, Datasheet, http://voith.com/de/555_e_g_1607_regioswing_e.pdf, accessed 28.01.2014.

[18] UNIFE and UIC, Technical Recommendation - Specification and verification of energy consumption for railway rolling stock, 2010.

[19] D. Wende, Fahrdynamik des Schienenverkehrs, Vieweg + Teubner Verlag | Springer Fachmedien, Wiesbaden, Germany, 2003.

[20] M. Meyer, Energieverbrauch und Energiesparmassnahmen bei elektrischen Bahnen, ETG-Fachtagung Elektrische Fahrzeugarchitekturen für Schienenfahrzeuge, Kassel, Germany, 25. September 2013.

[21] A. Steimel, Elektrische Triebfahrzeuge und ihre Energieversorgung, Oldenbourg Industrieverlag, München, Germany, 2006

[22] P. Hofmann, Hybridfahrzeuge, Springer, Wien, Austria, 2010.

[23] A. Dinger, M. Ripley et al., Batteries for Electric Cars Challenges, Opportunities, and the Outlook to 2020, The Boston Consulting Group, 2010.

[24] L. Lam and P. Bauer, Practical Capacity Fading Model for LiIon Battery Cells in Electric Vehicles, IEEE Transactions on Power Electronics, Vol. 28, No. 12, pp. 5910-5918, December 2013.

[25] A. Millner, Modeling Lithium Ion battery degradation in electric vehicles, 2010 IEEE Conference on Innovative Technologies for an Efficient and Reliable Electricity Supply (CITRES), Waltham, MA, USA, pp. 349-356, 27.-29. September 2010.

[26] ApECOR, EV Bi-Directional DC-DC, Datasheet, http://apecor.com/pages/products/highpower/apecor_ev_bidirect ional_dcdc.pdf, accessed 28.01.2014.

[27] B. Madden and R. Zaetta, Hydrogen Fuel Cell Bus Technology State of the Art Review, NextHyLights Deliverable Nummer 3.1, February 2011.

[28] C. Guzy, Ballard - Putting Fuel Cells to Work, Presentation on ZBus Regulation and Technology Summit and Workshop, Diamond Bar, CA, USA, September 2013.

[29] W. Ahluwalia and R. Kumar, Fuel Cell Transit Buses, Report of the Argonne National Laboratory Argonne, IL, USA, January 2012.

[30] S. Richardson, Economics of Commuter Rail Alternatives Comparative Cost Perspective, Transportation Research Record: Journal of the Transportation Research Board, No. 1887, TRB, National Research Council, Washington D.C., pp. 99-105, 2004. 